\title{
The Impact of Organic Fertilizers on Production of Organic Greenhouse Cucumber
}

\author{
Yadollah Tavakoli \\ Lecturer and Researcher in Islamic Azad University, Jiroft Branch \\ Sibgol Khoshkam \\ Lecturer and Researcher in the Agricuture Reaserch Center, Jiroft and Kahnoj
}

\author{
Doi:10.5901/mjss.2013.v4n14p249
}

\begin{abstract}
The present experiment was conducted within the framework of randomized completed block design (RCBD) with 6 treatments and 4 replications in the research greenhouse of the educational farm in Islamic Azad University, Jiroft branch to investigate the impact of organic fertilizers on yield of greenhouse organic cucumber crops. The treatments included: (1) compost+poultry manure; (2) compost+cow manure; (3) poultry manure+compost+biological nitroxin fertilizer; (4) cow manure +compost +biological nitroxin fertilizer; (5) cow manure+compost+poultry manure+biological nitroxin fertilizer and finally (6) the control (regional custom and routine). The findings indicated that many growth and yield parameters at $p<0.01$ were significantly affected by the cultivation beds. In general, the results indicated that due to their considerable performance, the mixed bed of compost, poultry manure, cow manure, and biologic fertilizer led to an increase in cucumber yield and could be utilized as the proper bed to produce greenhouse organic cucumber.
\end{abstract}

Keywords: organic, greenhouse cucumber, organic fertilizers, Jiroft, Islamic Azad University.

\section{Introduction}

Cucumber is a year-long market-garden plant from Cucuerbitaceae family and Cucumis sort, which has the scientific name Cucumis Stivus. Based on recent statistics, this plant was cultivated in 78197 hectares of land in Iran in 2011. Jiroft and Kahnooj were the top cucumber cultivation zones in Iran - with 19500 hectares accounting for $20 \%$ of the whole area under cucumber cultivation. Iran has secured around $3.2 \%$ of the world's cucumber cultivated areas. According to the latest statistics, this product is being exported in various ways to target countries such as Iraq, Azerbaijan, Armenia, Afghanistan, Sweden, Kuwait, and the Netherlands. An important challenge facing greenhouse cucumber consumers is the issue of safety and healthiness. Population crisis and limited production resources have resulted in a shift from traditional agriculture towards industrial and technology-oriented agriculture following the agricultural green revolution in 1950s. Green revolution in agriculture was concomitant with advent of technologies such as chemical fertilizers, highly yielding cultivars, new irrigation methods, new machinery, etc. The intent of green revolution was to obtain higher levels of crops production to fulfill the world growing population's need for food. However, only within two decades from the advent and application of chemical fertilizers, the production process encountered new series of problems mostly rooted in inconsiderate and inappropriate application of fertilizers as well as other new technology products.

New problems, resulting from new technologies, were even far worse than those in the traditional agriculture era. The introduction of chemical fertilizers into the agricultural sector has not only endangered the healthiness of the product but it has also impacted its quantity. The application of new technology products in agriculture, including chemical fertilizers, has given rise to new pests and diseases in farms. That is, following the application of pesticides, a small percentage of pests show resistance against the poison - those that do not are eliminated immediately. In fact, the resistant ones survive by multiplication and transfer the resistant genes to the next generations. This is extremely dangerous because resistant pests will survive the conventional pesticides. This instigates farmers to apply more and newer types of pesticides. Such problems, since 1980s, have caused agricultural experts to pay special attention to organic farming.

Being an important greenhouse product in Iran, particularly in Jiroft region, cucumber ranks first in terms of total production and cultivation area. Its rate of consumption in the society is extremely high and it is often consumed fresh. The problem is that cucumber is mostly cultivated under plastic covers in low tunnels and greenhouses where the rate of 
poison residuals and chemical fertilizers is higher than the open space. The abundant consumption of fertilizers and pest control chemicals such as pesticides, weed killers and fungicides is hazardous both for the consumers and the farmers' health. In fact, the side-effects and durability of such chemical is much greater in greenhouses than in the open space they may destroy the tissue and structure of the soil and the environment as they may contaminate the underground waters.

This necessitates introduction of new methods to increase the yield and the quality of the product. To attain this objective, soil-inhabiting living organisms known as biological fertilizers have been introduced to safeguard the soil biological system in farmlands. Feeding the soil with organic material is considered the most important benefit of these fertilizers (Ghafarinejad, 2008). Use of sheep, cow, and poultry manures, along with compost, has long been used in greenhouse cucumber cultivation. Presently, poultry manure is the only fertilizer used primarily in greenhouses of the region. Despite its positive effects in boosting the greenhouse cucumber crop yield and quality, it still remains to be the most expensive organic fertilizer in the region (ibid). Its overuse by greenhouse owners in the region (30-50 tons in hectares) ends up in an increase in phosphor and salinity level in the soil, the latter making the plant vulnerable to fungal diseases like wave spot and false mildew. Moreover, with salinization, there appear cracks on the ring spot of the plant, giving way to the disease-causing fungoid agents such as Fitium, Fitoftora, etc. which ultimately leads to plant death and vessel diseases. The highest yield, stem diameter and biomass content was obtained from Coco Peat and Perlite - Coco peat beds, and a significant difference was observed $(p<0.05)$ in some growth indices such as fruit number and plant biomass. Yet, the yield, stem diameter, and leaf surface index showed no significant difference. In all, the optimal growth rate was obtained from cocopit cultivation bed implying its applicability as an appropriate cultivation bed for cucumber in soilless cultivation (Kucinskas \& Karbauskiene, 2000).

\section{Literature Review}

In their study, Tuzel (2001) investigated the effect of cattle manures on soil biological properties. He concluded that use of cattle manures could significantly increase the number of fungi, actinomycetes, bacteria, phosphate-solving bacteria, organic phosphor-mineralizing bacteria, phosphor solubility, mineralization of phosphor, as well as enzyme respiration and activity in soil.

Ghafarinejad (2008) reported that Phosphor, compared to nitrogen and sulphur, had higher applicability in organic fertilizers. Based on the findings, phosphor was found to have the best applicability, compared to nitrogen and sulphur, in cow manure.

Youssef, El- Fouly and Mohamedien (2001) obtained the best results for Pumice treatment with cattle manure by comparing 8 cultivation environments for lettuce. In an experiment using manure in the form of processed organic humus, the quality of the tomato product was observed to have increased compared to the time when manure was merely used. Further, the use of poultry manure was found to have led to an increase in plant height and fruit size in tomatoes cultivated in low tunnels.

In their experiment on lettuce, Turhan, Sevgican and Tuzel (1999) examined three sources, namely, animal manure, compost, and phospho-compost. The results indicated that all plant growth factors were affected by the organic fertilizer sources among which the animal manure and phospho-compost exerted the highest impact on the crop production.

Engindeniz, S \& Tuzel, Y. (2002 \& ) oncluded that use of organic fertilizers in a sodium soil could reduce pH, Ec, and ESP, and hence minimize low-consumption elements. The study of three organic fertilizers, namely, cow, swine, and poultry manure, revealed that use of such fertilizers could increase the lettuce yield up to $37 \%, 43 \%$, and $98 \%$, respectively. The recycling of nitrogen from poultry manure was $38-82 \%$, urea $51-69 \%$, cow and swine manure $10-25 \%$.

\section{Materials and Method}

The present research was conducted within 2010-2011 in one of the greenhouses of the educational farm affiliated to $I A U$, Jiroft branch with a latitude of $26^{\circ}$ and $35^{\prime} \mathrm{N}$, and the longitude of $56^{\circ}$ and $17^{\prime} \mathrm{E}$. To undertake the study, Randomized Complete Block Design (RCBD) was used with 6 treatments and 3 replications. The treatments included: 1. Compost+poultry manure, with equal proportions, 10 tons per hectare; 2 . Compost+cow manure+poultry manure, with equal proportions, 10 tons per hectare; 3. Poultry manure+compost, with equal proportions, 10 tons in hectare plus biological nitroxine fertilizer (4 liters per hectare); 4. Cow manure+compost, with equal proportions, 10 tons per hectare plus biological nitroxin fertilizer (4 liters per hectare); 5. Cow manure+Compost+poultry manure, with equal proportions, 
10 tons per hectare plus biological nitroxin fertilizer (4 liters per hectare); and 6. The control group (regional custom and routine) to disinfect the greenhouse cultivation bed. Subsequent to the end of growth period and the previous cultivation season, the bed soil was properly disinfected for 2 months (from late June to late August) by inundating the cultivated land, protecting it with plastic cover, and exposing it to summer sun. Thereby, the crop cultivation bed in the greenhouse was disinfected without using any chemical poisons. In order to provide the transplants, the cucumber seeds were kept in a well-quarantined nursery and were cultivated in sterile transplant boxes using compost cultivation bed, sand, and garden soil. By so doing, a fully sturdy and healthy transplant was prepared and then transferred to the greenhouse.

To provide proper ventilation, air conditioning systems (fan and pad system) were installed inside the greenhouse and side windows with insect screens were opened (the screen was capable of letting the air in and out for proper ventilation as its meshes were the size enough to exclude tiny insects like thrips and white flies from the greenhouse). High temperature and humidity were avoided to prevent the outbreak of various fungus diseases inside the greenhouse. To avoid frost damage in cold nights of the cultivation season, gasoline-powered heaters were installed at $1000 \mathrm{~m}^{2}$ intervals keeping the greenhouse warm for ten hours at night.

Before cultivation, samples were collected from 0 to $30 \mathrm{~cm}$ depths to determine the physical and chemical properties of farm soil, demonstrating that the soil texture was loam with a pH of 7. At first, the fertilizers were analyzed in terms of salinity, $\mathrm{pH}$, nitrogen, phosphor, potassium, iron, magnesium, zinc, and copper. Furthermore, irrigation, fighting the weeds, pests, and diseases as well as other agricultural protective measures were all carried out equally and in a similar way in all the treatments. The temperature and humidity of the greenhouse was controlled via heaters and the windows within a perimeter deemed optimal for crop growth. The extension for the growth and harvest periods was 8 months, and the harvest was carried out around 33 times and each time an average of 10 cases was statistically analyzed.

Early in the harvest period, the data related to the total yield, marketable yield, fruit quantity per unit of land, the average weight of a single fruit, diameter, length, and soluble solid content in the fruit juice and, at the end of the harvest, the ultimate height of the plant were all recorded. The obtained data was put into statistical analysis using SAS statistical software, and mean comparisons were undertaken through Duncan's multiple range test $(p<0.01$ and $p<0.05)$. The cultivated area was divided into 3 blocks according to operational plan of the plots. Each plot contained 20 plants, with data collection being carried out from the middle 10 plants.

Table 1. Greenhouse soil analysis

\begin{tabular}{|c|c|c|c|c|c|c|c|c|}
\hline $\begin{array}{c}\text { EC } \\
\mathrm{ds} / \mathrm{m}\end{array}$ & $\mathrm{pH}$ & $\begin{array}{c}\text { Percentage of organic } \\
\text { carbon }\end{array}$ & $\begin{array}{c}\text { Utilizable } \\
\text { phosphor }(\mathrm{ppm})\end{array}$ & $\begin{array}{c}\text { Utilizable potash } \\
(\mathrm{ppm})\end{array}$ & $\begin{array}{c}\mathrm{Fe} \\
(\mathrm{ppm})\end{array}$ & $\begin{array}{c}\mathrm{Mn} \\
(\mathrm{ppm})\end{array}$ & $\begin{array}{c}\mathrm{Zn} \\
(\mathrm{ppm})\end{array}$ & $\begin{array}{c}\mathrm{Cu} \\
(\mathrm{ppm})\end{array}$ \\
\hline 2.55 & 7.6 & 0.1 & 4.2 & 205 & 2.3 & 11.14 & 1.08 & 1.52 \\
\hline
\end{tabular}

Table 2. Water analysis

\begin{tabular}{|c|c|c|c|c|c|c|c|}
\hline SAR & $\mathrm{Cl}$ (mg/lit) & $\mathrm{Na}$ (mg/lit) & $\mathrm{Ca \& Mg}$ (mg/lit) & Bicarbonate $(\mathrm{mg} /$ /it) & Carbonate $(\mathrm{mg} / \mathrm{lit})$ & $\mathrm{pH}$ & $\mathrm{EC} \mathrm{ds} / \mathrm{m}$ \\
\hline 0.76 & 1.4 & 2.05 & 14.4 & 2.14 & 0.48 & 7.1 & 760 \\
\hline
\end{tabular}

Table3. Chemical analysis of utilized organic fertilizers

\begin{tabular}{|c|c|c|c|c|c|c|c|c|}
\hline Type of fertilizer & $\mathrm{Ec}^{*}(\mathrm{ds} / \mathrm{m})$ & $\mathrm{N} \%$ & $\mathrm{P} \%$ & $\mathrm{~K} \%$ & $\begin{array}{c}\mathrm{Fe} \\
(\mathrm{ppm})\end{array}$ & $\begin{array}{c}\mathrm{Mn} \\
(\mathrm{ppm})\end{array}$ & $\begin{array}{c}\mathrm{Zn} \\
(\mathrm{ppm})\end{array}$ & $\begin{array}{c}\mathrm{Cu} \\
(\mathrm{ppm})\end{array}$ \\
\hline Poultry & 23.5 & 2.14 & 1.025 & 2.59 & 1604.5 & 365.5 & 281.5 & 41 \\
\hline Compost & 12.10 & 1.99 & 0.474 & 1.29 & 2084.5 & 350 & 428 & 145 \\
\hline Cow & 17.07 & 1.02 & 0.328 & 1.20 & 1929 & 318. & 60 & 24 \\
\hline Biological & 11.02 & 0.78 & 0.132 & 0.64 & 2037 & 377.5 & 71 & 32 \\
\hline
\end{tabular}


Table 4. Comparison of the average effect of incorporating fertilizers on growth and yield of Royal 189 cultivar

\begin{tabular}{|l|c|c|c|c|}
\hline \multicolumn{1}{|c|}{ type of fertilizer } & $\begin{array}{c}\text { total yield } \\
(\mathrm{kg} / \mathrm{m} 2)\end{array}$ & $\begin{array}{c}\text { marketable yield } \\
(\mathrm{kg} / \mathrm{m} 2)\end{array}$ & $\begin{array}{c}\text { length of cucumber } \\
\text { plant }\end{array}$ & $\begin{array}{c}\text { Fruit number per } \\
\text { unit of area }\end{array}$ \\
\hline $\begin{array}{l}\text { cow manure+compost+poultry } \\
\text { manure+nitroxin }\end{array}$ & $8.74 \mathrm{a}$ & $8.18 \mathrm{a}$ & $5.70 \mathrm{a}$ & $102.38 \mathrm{a}$ \\
\hline poultry manure+nitroxin+compost & $8.72 \mathrm{a}$ & $8.12 \mathrm{a}$ & $4.20 \mathrm{a}$ & $104.23 \mathrm{a}$ \\
\hline cow manure+compost+nitroxin & $7.90 \mathrm{~b}$ & $7.52 \mathrm{~b}$ & $5.93 \mathrm{a}$ & $95.95 \mathrm{~b}$ \\
\hline compost+poultry manure & $7.61 \mathrm{~b}$ & $7.878 \mathrm{~b}$ & $5.43 \mathrm{a}$ & $92.19 \mathrm{~b}$ \\
\hline compost+cow manure & $5.93 \mathrm{c}$ & $5.43 \mathrm{c}$ & $5.12 \mathrm{a}$ & $90.06 \mathrm{c}$ \\
\hline control & $5.45 \mathrm{c}$ & $4.19 \mathrm{c}$ & $5.13 \mathrm{a}$ & $88.924 \mathrm{c}$ \\
\hline
\end{tabular}

*Means marked with the same letter in each column or row are not significantly different $(p<0.05)$

Table 5. Comparison of the average effect of fertilizers on qualitative parameters of Royal 189 cultivar

\begin{tabular}{|l|c|c|c|c|}
\hline \multicolumn{1}{|c|}{ Type of fertilizer } & $\begin{array}{c}\text { Average fruit weight } \\
(\mathrm{gr})\end{array}$ & $\begin{array}{c}\text { Fruit length } \\
(\mathrm{cm})\end{array}$ & $\begin{array}{c}\text { Fruit diameter } \\
(\mathrm{cm})\end{array}$ & $\begin{array}{c}\text { Percentage of soluble } \\
\text { solid content }\end{array}$ \\
\hline $\begin{array}{l}\text { cow manure+compost+poultry } \\
\text { manure+nitroxin }\end{array}$ & $95.33 \mathrm{a}$ & $15.624 \mathrm{a}$ & $2.75 \mathrm{a}$ & $3.6 \mathrm{a}$ \\
\hline poultry manure+nitroxin+compost & $93.265 \mathrm{a}$ & $15.4 \mathrm{a}$ & $2.81 \mathrm{a}$ & $3.5 \mathrm{a}$ \\
\hline cow manure+compost + nitroxin & $95.52 \mathrm{~b}$ & $15.4 \mathrm{a}$ & $2.52 \mathrm{a}$ & $3.3 \mathrm{a}$ \\
\hline compost + poultry manure & $91.97 \mathrm{~b}$ & $15.52 \mathrm{a}$ & $2.31 \mathrm{~b}$ & $3.41 \mathrm{a}$ \\
\hline compost + cow manure & $84.679 \mathrm{c}$ & $15.23 \mathrm{a}$ & $1.97 \mathrm{c}$ & $3.55 \mathrm{a}$ \\
\hline control & $81.25 \mathrm{c}$ & $15.462 \mathrm{a}$ & $1.09 \mathrm{c}$ & $3.5 \mathrm{a}$ \\
\hline
\end{tabular}

*Means marked with the same letter in each column or row are not significantly different $(p<0.05)$

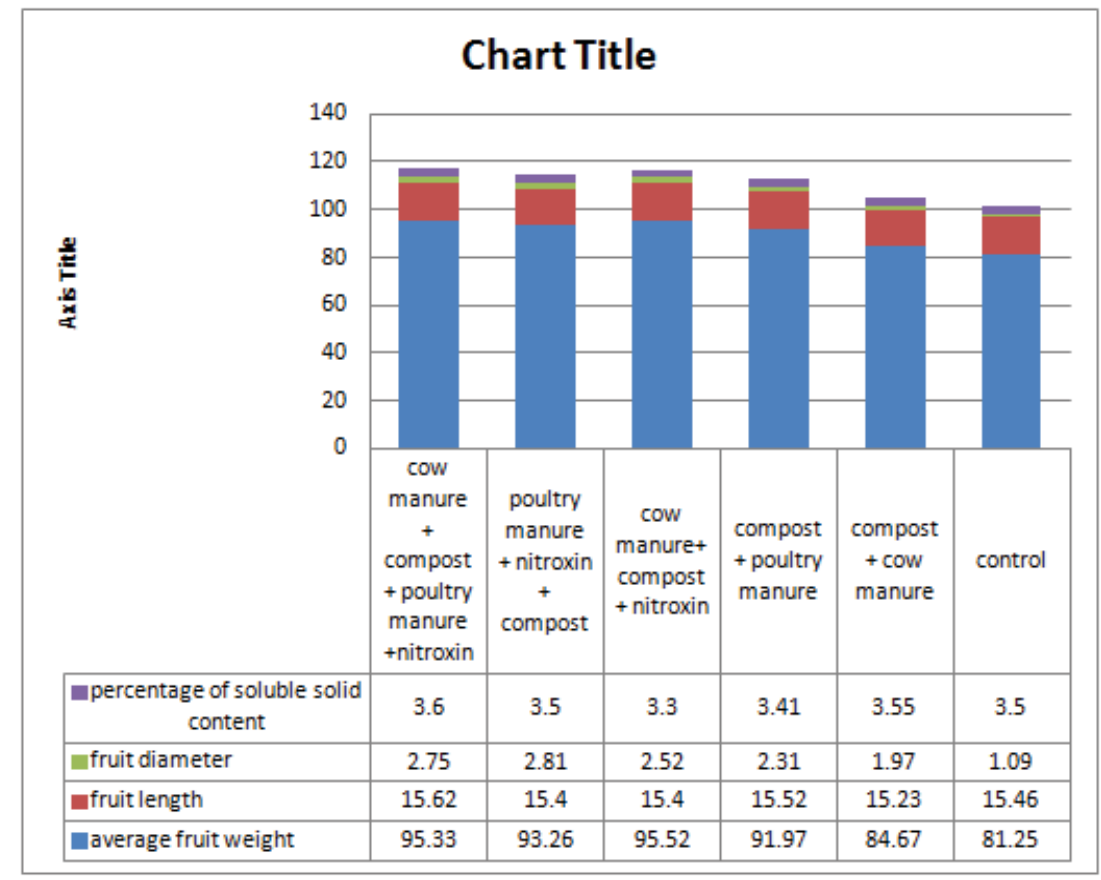

\section{Results and Discussion}

Analyzing the total variance of the data indicated that the effect of cultivation beds on all the parameters was significant. The total yield, the marketable yield, plant length, fruit number per unit of area, average fruit weight, fruit length, and fruit 
diameter were the parameters exhibiting different effects due to treatment. However, only the effect of treatments on the soluble solid content showed no significant difference indicating that organic fertilizers had increased the abovementioned parameters. Table 4 represents the average effect of organic fertilizers on crop yield. As indicated the highest total yield of $8.78 \mathrm{~kg} / \mathrm{m}^{2}$ belonged to the treatment comprising use of a combination of compost, cow and poultry manure as well as biological fertilizers while the lowest yield belonged to the control treatment with $5.45 \mathrm{~kg} / \mathrm{m}^{2}$. As for the marketable yield, similar results were observed, that is, the highest marketable yield of $8.18 \mathrm{~kg} / \mathrm{m}^{2}$ belonged to the treatment comprising compost, cow and poultry manure as well as biological fertilizers while the lowest one was 4.19 $\mathrm{kg} / \mathrm{m}^{2}$ found in the control treatment. The fruit number per unit of area, too, revealed a significant difference: the highest number of fruits per unit of area for the treatment with cow, compost, poultry, as well as biological fertilizers was 102.38 while the lowest number was reported to be 88.92 for the control treatment. The rest of the treatments were significantly different from the control group indicating that use of a combination of organic fertilizers had increased significantly fruit number per unit of area and the total yield. The average fruit weight in treatments involving organic fertilizers showed a significant difference from the control group. The highest average fruit weight $(95.33 \mathrm{~g})$ was observed in treatment using cow, compost, poultry, and biological fertilizers. This was significantly different from the control group $(p<0.01)-$ The lowest average fruit weight in the control treatment was $81.25 \mathrm{~g}$. Moreover, the fruit length was significantly different in the treatment group demonstrating that use of organic fertilizers had led to a rise in the total fruit yield by increasing fruit quantity per unit of area and also fruit diameter. Compared to the control group, the fruit diameter exhibited a significant difference in all treatments involving organic fertilizers; the highest number for the fruit diameter was $2.75 \mathrm{~cm}$ in treatments with compost, cow and poultry manure as well as biological fertilizers, and the lowest number was $1.09 \mathrm{~cm}$ in the control treatment. The percentage of soluble solid content did not show any significant difference in any of the treatments.

Achieving greater yields is deemed as one of the most important advantages of compost. Besides, its humidity preserving capacity is remarkable. As for other organic fertilizers, its capillary property is strong and capable of preserving water 3-4 times its own weight. These two points result in an increase in the capacity of preserving the nutritional solution; better exchange of elements inside the beds, and proper distribution of humidity in the root environment. This latter point is significant since it forms a root system and increases absorption of nutrients, thereby giving rise to a robust plant growth and greater crop yield.

\section{Concluding Remarks}

Based on the findings, since usage of chemicals induces numerous problems and endangers crop health, its application in organic products is not justifiable. In this study, organic fertilizers were shown to have increased yield and healthiness of the crops compared to chemical fertilizers. Thus, organic fertilizers could be proposed as a solution to organic crops production, esp. greenhouses where concentration of destructive elements is higher than the open space. As shown in Table 4, the effect of organic fertilizers on the total cucumber yield is significant. Comparing the means via Duncan test (Table 5) indicates that poultry manure, ranking first, has led to a significant increase in the yield as compared to other fertilizers. Compost, cow manure, and biologic fertilizers held the other ranks, respectively (Table 3). The density of nutrients in these fertilizers is similar to the effect they had on the increase of cucumber yield. This means that from among the above sources, poultry manure is the richest. Based on the findings, it could be maintained that consuming organic fertilizers in compost form, while increases the plant yield, has positive impact on the physicochemical properties of soil which, in turn, results in preserving soil health and fertility as well as stability in production in the long run.

\section{References}

Engindeniz, S \& Tuzel, Y. (2002). The Economic analysis of organic greenhouse tomato production: a case study for Turkey. Agro Food Industry Hi-Tech, 13, pp. 26-30.

Engindeniz, S \& Tuzel, Y. (2006). Economic analysis of organic greenhouse lettuce production in Turkey. Izmir (Turkey): Department of Agricultural Economics, Bornova.

Ghafarinejad, S. A. (2008). Final report of the research proposal on the effect of levels and sources of organic fertilizers on greenhouse cucumber yield and quality in Jiroft region. Jiroft and Kahnooj Shahid Moghbeli Agricultural Research Center.

Kucinskas, J. \& Karbauskiene, E. (2000). Cucumber fertilization by Vermicompost. Sodininkyste- Ir-Darzininkyste. 19(3), pp. 46- 54.

Sreenivas, K. N. \& J. V. N. Gowda (1999). Effect of different organic manures on growth and flower yield of China Aster. CropResearch- Hisar. 18(1), pp. 104-107.

Turhan. E., Sevgican, A. \& Tuzel, Y. (1999). Effect of different growing media on greenhouse lettuce growth in soilless culture. Proceeding of the International Symposium on Greenhouse Management for Better Yield and Quality in Mild Winter Climates. 
Turkey, 405-408.

Tuzel, Y. (2001). Organic vegetable growing in greenhouses. Regional WG Greenhouse Crop Production in the Mediterranean Region Newsletter, 8, pp. 7-17.

Youssef, A. M., El-Fouly, A. H. M. \& Mohamedien, S. A. (2001). Effect of using organic and chemical fertilizers in fertigation system on yield and fruit quality of tomato. Egyptian Journal of Horticulture, 28(1), pp. 59- 77. 